\title{
RELIGIOUS DIMENSION OF COMPUTER GAMES
}

\author{
Anton Sukhov \\ Assoc .Prof. Dr., Ural Federal University named after the first President of Russia B. N. \\ Yeltsin, Russian Federation, suhovband@mail.ru
}

\begin{abstract}
Modern computer games are huge virtual worlds that raise sophisticated social and even religious issues. The "external" aspect of the religious dimension of computer games focuses on the problem of the polysemantic relation of world religions (Judaism, Christianity, Islam, Buddhism) to computer games. The "inner" aspect represents transformation of monotheistic and polytheistic religions within the virtual worlds in the view of heterogeneity and genre differentiation of computer games (arcades, action games, role-playing games, strategies, simulators, hybrid genres).
\end{abstract}

Keywords: computer games, religion, game studies, religious studies, virtual reality, Judaism, Christianity, Islam, Buddhism, arcades, action games, shooters, role-playing games, strategies, simulators.

\section{INTRODUCTION}

Computer games are interesting complex phenomenon of contemporary culture, vivid example of the fast development of audiovisual technologies. If the first computer games were simple entertaining arcades with primitive video graphics and gameplay, many modern computer games have become huge virtual worlds (like "The Elder Scrolls V: Skyrim" (2011), "Total War: Attila" (2015) or "Mass Effect: Andromeda" (2017) with thousands of different characters, events, locations in millions of colors and with interactive surround sound. This extraordinary experience of immersion in virtual worlds of modern computer games requires a lot of "real" time to complete the game and raise sophisticated philosophical, social, ethical, aesthetical, political, educational, economical, gender, sports, historical and even religious issues. At the same time, despite the broad presence of computer games in modern culture, the scientific exploration of this phenomenon, particularly in Russian scientific discourse, was insufficient and for the most part unsystematic. Research of computer games in the modern social sciences and humanities is a relatively new trend. This also applies to the insufficiently investigated religious dimension of computer games, which includes both the problem of the polysemantic relation of world religions to modern computer games and the representation and transformation of religions within the virtual worlds of computer games.

\section{METHODOLOGY}

Methodologically it is possible to identify two main problematic aspects in the study of the religious dimension of computer games: "external" and "internal". The external aspect focuses on the problem of the relation of world religions (Judaism, Christianity, Islam, Buddhism) to computer games as to "external» object for them. This research first analyzes a wide range of relevant sources, both canonical (sacred texts) and modern (including actual theses of authoritative contemporary religious leaders). Second, the research 
considers historical, cultural and regional characteristics of the world religions. The inner aspect of religious dimension of computer games in terms of methodology more linked with the phenomenology of games. Here, in the view of heterogeneity and genre differentiation of computer games (arcades, action games ('shooters", "slashers", "fightings"), role-playing games, turn-based and real-time strategies, transport and economic simulators, various hybrid genres) we will analyze how monotheistic and polytheistic religions represent and transform within the virtual worlds of computer games.

\section{3 “EXTERNAL" ASPECTS OF THE RELIGIOUS DIMENSION OF COMPUTER GAMES}

Most of traditional monotheistic religions refer to videogames quite cautiously. This can be explained by the fact, that computer games are relatively young phenomenon of world culture. That is why in religious discourse has not yet emerged a serious discussion, which may systematically considers all the capabilities of virtual worlds of computer games. The existing reflection in modern religious discourse usually concerns issues of computer game addiction and the problem of violence in video games.

\subsection{Contemporary Judaism}

Contemporary Judaism marks immersion to the virtual worlds mostly negative. For instance, Ashkenazi exChief Rabbi of Israel Jonah Metzger said computer games "cultivate violence" (Interfax, 2005, http://www.interfax-religion.ru/arm/?act=news\&div=6858). Another famous Jewish religious leader rabbi Eliyahu Essas also expresses the same negative attitude towards computer games and claims that "socalled "role-playing games" that move a person into a virtual fantasy world, where he ostensibly fights monsters do not carry anything but the destruction of the human personality" (Essas, 2013, https://www.evrey.com/sitep/askrabbi1/q.php?q=0tvet/q4299.htm). In fact, he claims that destroying and humiliating of virtual enemies and the use of various methods of violence (permitted by the game) "only reinforces negative inclinations" (Ibid.) because gamers may sometimes use these methods of violence in a real life. Miriam Klimovskaya from the internet portal "Judaism and the Jews" reveals another negative effect of virtual addiction. She asserts that emotions initially required for real life "are wasting on the virtual life and not leaving a person mental strength to solve real life problems" (Klimovskaya, 2014, https://toldot.ru/ffamily/children/children-ask 7884.html). Thus, in contemporary Judaism prevails almost critical attitude to computer games.

\subsection{Contemporary Christianity}

\subsubsection{Contemporary Orthodox Christianity}

Contemporary Orthodox Christianity, for the most part, defines playing computer games also as a kind of harmful pastime. Patriarch of Moscow and All Russia Alexy II said, "computer games promote the cult of violence, convince us that human life is worth nothing" (Lipich, 2004, https://ria.ru/society/20040421/574130.html). Archbishop of Ekaterinburg Vikentiy in 2004 considered turnbased strategy game "Heroes of Might \& Magic" as a sin. This orthodox attitude to the games psychotherapist and priest Gregory Grigoriev explains by the fact, that "the player digs his talent into the ground and runs away from the God" (Milovidov, 2013, http://www.nsad.ru/articles/mozg-ne-rasschitan-nakompyuternye-igry). While the "whole life should be useful and busy with good works, should be joyful and active movement to the Kingdom of Heaven, to the loving Father, God. The game is a passive withdrawal from this movement. Moreover, there is a departure from the God" (Ibid.). At the time of the game, we do not deal with "acquisition of the grace of the Holy Spirit" (Motovilov, 2010, http://lib.pravmir.ru/library/readbook/1448). According to saint Seraphim of Sarov this is the goal of the Christian life. In other words, "computer games activate earth "passions" instead of human movement to the Kingdom of Heaven (Sukhov, 2016, p.664) and distract from the spiritual life.

\subsubsection{Modern Catholicism}

Despite all the dogmatic differences between Eastern and Western Christianity the same logic is presented in modern Catholicism. Pope Benedict XVI directly blamed video games "which in the name of entertainment exalt violence and portray anti-social behaviour or the trivialization of human sexuality is a perversion, all the more repulsive when these programmes are directed at children and adolescents" (Benedict XVI, 2007, https://w2.vatican.va/content/benedict-xvi/en/messages/communications/documents/hf ben-

xvi mes 20070124 41st-world-communications-day.html). His successor, Pope Francis compares gamers to "vegetables" and consistently criticizes modern technologies, which deprive too much time. Pope Francis challenges young people "to reject video games and engage in social activism instead" (Scislowska, d'Emilio, 2016, http://www.independent.co.uk/news/world/europe/pope-francis-urges-young-people-to-rejectvideo-games-and-engage-in-activism-instead-a7164376.html). Thus, a similar to Orthodox motive can be 
IJASOS- International E-Journal of Advances in Social Sciences, Vol. III, Issue 8, August 2017

traced here, however, not the problem of distraction from spiritual life is emphasized, but the actualization of the issues of social activism which are typical for modern Catholicism after the Second Vatican Council.

\subsubsection{Canonical Basis}

The basis of mostly cautious attitude of contemporary Christianity to virtual entertainment can be deduced from the canonical sources. Saint apostle Paul in the Epistle to the Corinthians writes, "Everything is permissible for me, but not everything is beneficial. Everything is permissible for me, but I will not be mastered by anything" (1 Corinthians 6:12). Although in the authoritative interpretation of the Apostle Paul, St. John Chrysostom refers it to gluttons, it is quite possible to shift it to the electronic entertainment of modern computer games. In this regard it is relevant to quote saint Clement of Alexandria who said that "If it is permissible to choose any life, it is obvious (to select) a life in the abstinence" (Clement of Alexandria, 2017, http://bible.optina.ru/new:1kor:06:12).

\subsection{Contemporary Islam}

\subsubsection{Modern Islamic Attitude to Computer Games}

The point of view of contemporary Islam on the discourse of computer games is more complicated. Khatib and Imam Sheikh Muhammad Saal al-Munadzhid from Saudi Arabia claims that computer games "are allowed as long as they do not distract man from his duties such as correct prayer or duty to the parents and do not contain anything forbidden" (Muhammad Saal al-Munadzhid, 2014, http://islam.com.ua/obschestvo-ikulytura/drugoe-chast-2/10281-kompyyuternye-igry). For example, the mention of so-called pagan "gods" in computer games, because this mention can be regarded as a violation of the monotheistic principle. In addition, other types of "forbidden" may be different game situations, when a player can fight against Muslims in the troops of "unbelievers" or "images of open women, illegal foods and drinks, gambling" (IslamToday, 2016, http://islam-today.ru/veroucenie/vopros-otvet/mozno-li-musulmaninu-igrat-v-komputernye-igry/) and anything that can be regarded as perversions in Islamic culture.

\subsubsection{Canonical Basis}

In the Hadiths (containing sayings of the prophet Muhammad) it is possible to find the historical roots of the attitude of contemporary Islam to computer games. Abu Berza al-Aslami reports that the Messenger of Allah said "on the day of judgment, a single slave will not move from his place until he answers the following questions: how he spent his life and what he spent it on; what he did with the knowledge; how he acquired property and what he spent on" (Tirmizi, Kyyama, 2417). Based on this hadith, computer games as a kind of virtual entertainment can be regarded as pointless activity and wasting of time.

\subsection{Modern Buddhism}

Unlike the Abrahamic religions, modern Buddhism refers to computer games more tolerantly and, on the contrary, emphasizes their value in the sense of psychotherapy. Karmapa Lama (head of the Karma Kagyu line of the Kagyu school of Tibetan Buddhism) Urgyen Trinley Dorje said, "the aggression that comes out in the video game satiates whatever desire I might have to express that feeling. For me, that's very skilful because when I do that I don't have to go and hit anyone over the head" (Rashmee, 2009, http://timesofindia.indiatimes.com/home/sunday-times/all-that-matters/Video-war-games-satiate-my-feelingsof-aggression/articleshow/5032672.cms). In fact, he equates modern computer games to traditional Buddhist meditation. Urgyen Trinley Dorje named computer games "emotional therapy", which can reduce stress by dissolving feelings of aggression in the virtual worlds.

\subsection{Neo-Pagan Cults}

Various modern forms of neo-paganism usually do not directly actualize the discourse of computer games. However, pseudo-pagan cults are widely represented in the virtual worlds of modern computer games in the genres of action games and role-playing games.

\subsection{Conclusions}

In general, although there are examples of a positive attitude to computer games, in religious consciousness prevails mostly negative attitude to computer games. This can be explained by the actual reduction of the whole variety of games to some problem genres ("shooters" or neo-pagan role-playing games) which explicitly represent the virtual violation of main commandments (for example, the first commandment of monotheism or the commandment "do not kill"). In addition, negative attitude can be explained by insufficient acquaintance with the products of the modern game industry, ignoring the practical value of computer games, their aesthetic, ethical and, in particular, innovative educational resources (for example, simulators of 
IJASOS- International E-Journal of Advances in Social Sciences, Vol. III, Issue 8, August 2017

the surgeon, helping to rehearse medical operations, flight simulators for training pilots of civil airlines and planning their actions in emergencies, etc.).

\section{4 “INTERNAL" ASPECTS OF THE RELIGIOUS DIMENSION OF COMPUTER GAMES}

Second, the inner aspect of religious dimension of computer games methodologically more linked with the phenomenology of games. Here, in the view of heterogeneity and genre differentiation of modern computer games we will analyze how religions represent and transform within the virtual worlds of computer games.

\subsection{Arcades}

In the simple arcade games the philosophical questions of religion are not the center of attention in the gameplay, because the main task of the player is to perform a specific mission and quickly go to the next level. Nevertheless, religious elements use in game design. For example, a representation of the ancient Egyptian cult in shareware games or the different ghost characters in discrete levels of legendary 'Pac-Man' arcade game (1980).

\subsection{Action Games}

The action genres of computer games (including "shooters", "slashers", "fightings" or different actionadventures) usually do not raise complex religious issues, because the main task of the player in these games as well as in arcades is also to quickly perform a specific mission. However, in some action games it is possible to find of a number of characters from the pantheon of polytheistic religions. For example, the battle with Angra Mainyu (Ahriman) in the action-adventure game "Prince of Persia" (2008), ancient Egyptian deities in the series of shooters "Serious Sam" (2001-2017), followers of pagan voodoo cult in a third person action game "Shadow Man" (1999), pseudo-pagan practices and supernatural essences in the series of "Wolfenstein" shooters (1981-2015). We also should note that visually and audially appalling images of some creatures from pagan culture (different monsters and "zombies") shows "not only an ethical but also the aesthetic polarization" (Sukhov, 2016, p. 667) of computer characters. Less often, it is possible to find the elements of traditional monotheistic religions, for example, a representation of historical religious contradictions of Sunnis, Shiites, Orthodox and Catholics during the Third Crusade in "Assassin's Creed" (2007) action-adventure game. In an applied context in some action games (usually in shooters) players may use so called "god mode" which usually means an invulnerability to any damage (without obvious reference to any existing religious tradition).

\subsection{Role-Playing Games}

Multidimensional virtual worlds of nonlinear role-playing games (RPG) represent not only material, but also spiritual culture. That is why RPG often raise religious topics. Due to the fact that most of RPG are not strictly historical, but represent fiction fantasy world ("The Elder Scrolls" series (1994-2014), "Dragon Age" series (2009-2014) or a fantastic world of the future ("Mass Effect" series (2007-2017), religions more often represented by a variety of polytheistic pseudo-pagan cults. In a famous RPG "The Elder Scrolls III: Morrowind" (2002) it is possible to find a multi-page virtual book named "Cults of Tamriel" with a detailed description of this religious system. Although in the virtual worlds of RPG prevails a variety of previously mentioned fantastic pseudo-pagan cults, sometimes it is also possible to find the representation of historical polytheistic pagan cults, mostly in a more simple type of role-playing games, so-called "ARPG" (action roleplaying games). For example, Greek Olympic cult in "Titan Quest" (2006) or Scandinavian pantheon in the newest game "Vikings: Wolfs of Midgard (2017). There are few analogues of world monotheistic religions. We can remember pseudo-Catholicism in "Divinity 2" (2009) or, on the contrary, canonically true Judaism in "FIVE: Guardians of David" (2015) based on the Old Testament. At the conceptual level, role-playing games also use some famous notions from religious discourse. For example, the concept of "karma" in the postapocalyptic virtual world of "Fallout" series (1997-2015). However, despite the obvious connotations with the Indian spiritual culture, this "karma" does not focus on the next incarnations in the wheel of Samsara, but strictly determines the current gameplay. In fact, such "karma" is just the sum of points "of good and bad behavior in the form of ranking that determine the basic attitude of non-player characters (unplayable computer characters) to the player" (Sukhov, 2016, p. 667).

\subsection{Strategies}

In the genre of pseudo-historic strategies all types of religions presented mostly neutral and tolerant. In "Civilization 4" (2005, one of the games of the world famous "Civilization" series) all religions are equal by parameters. This fact can be explained by the principles of political correctness and tolerance, which are dominated in contemporary Western culture. The historical strategies like "Total War: Medieval 2" (2006) represent specific historical religious elements, for example, Crusades, auto de fe, jihad, the spread of Islam. 
Recently released hybrid of role-playing game and turn-based strategy "Legends of Eisenwald" (2013) directly represents the medieval Catholic Church, priests, and constantly mentions the real Christian saints. This is extremely rare for modern computer games in general.

\subsection{Simulators}

The majority of transport simulators are religiously neutral (paradoxically as their opposite, arcade games), because most often they represent the possibility to control a wide range of various modes of transport, from a motorcycle to a spaceship. Complex hybrid economic simulators ("SimCity" series, 1989-2013) represent religious organizations and actualize moral dilemmas in the city management, which player may solve even by the creation of virtual Armageddon. Another interesting type of hybrid simulator/strategy games which is directly connect with religious discourse is so called "god game". In a "god game" a player may have supernatural powers, can create "miracles" and rule his own tribe of people, for example in the famous "Black \& White" god game (2001). Almost every mission in the game has "good" and "evil" solutions. A player has a choice to achieve the desired intention by a brute force or by the good deeds. In fact, the gameplay of "Black and White" raises complex ethical issues and actualize the dialectics of good and evil in decisionmaking.

\section{CONCLUSIONS}

There are two main problematic aspects in the study of the religious dimension of computer games: external and internal. The external aspect focuses on the problem of the relation of world religions to computer games. Contemporary Judaism, Orthodox Christianity and Catholicism marked immersion to the virtual worlds mostly negative (computer games cultivate violence and distract from the spiritual and social life). Modern Islam considers that computer games are generally allowed until they do not represent anything forbidden for Muslims. Unlike the Abraham religions, modern Buddhism emphasizes the psychotherapeutic value of computer games. In general, prevailing in religious consciousness negative attitude to computer games can be explained by: 1) the reduction of the whole variety of games to some "problem" genres which represent the violation of main commandments; 2) insufficient acquaintance with practical innovative educational capabilities of computer games. The inner aspect of the religious dimension of computer games represents transformation of religions within the virtual worlds in the view of genre heterogeneity of computer games. Religious issues are not in the center of the gameplay in arcade games. Action genres contain a set of bright characters from ancient oriental polytheistic religions. Due to the fact that most of RPG are not historical, but represent fantasy worlds or fantastic worlds of the future, religions are represented primarily by a variety of pseudo-pagan polytheistic cults. Most of strategy games represent specific historical religious elements and units. If the majority of transport simulators are religiously "neutral", economic simulators and hybrid strategy/simulator games actualize complex moral dilemmas and the discourse of religious ethics.

\section{REFERENCE LIST}

Benedict XVI. (2007). Message of the Holy Father Benedict XVI for the 41st World Communication Day "Children and the Media: a Challenge for Education" https://w2.vatican.va/content/benedictxvi/en/messages/communications/documents/hf_ben-xvi_mes_20070124_41st-worldcommunications-day.html

Bible. (2017). https://www.bible.com/

Can a Muslim play computer games? (2016). Islam-Today. http://islam-today.ru/veroucenie/voprosotvet/mozno-li-musulmaninu-igrat-v-komputernye-igry/

Chief Rabbi of Israel spoke against aggressive computer games. (2005). Interfax. http://www.interfaxreligion.ru/arm/?act=news \&div=6858

Clement of Alexandria. (2017). Stromata. Interpretation of the Holy Scripture. http://bible.optina.ru/new:1kor:06:12

Essas E. (2013). How does Judaism and the Torah relate to the Internet? https://www.evrey.com/sitep/askrabbi1/q.php?q=otvet/q4299.htm

Kaya M. (2014). 250 Hadiths with Commentary on the Standards of Life of a Muslim. 
https://vk.com/islam_books

Klimovskaya M. (2014). Is it bad to play computer games? For example, in FIFA? Judaism and the Jews. https://toldot.ru/jfamily/children/children-ask_7884.html

Lipich O. (2004). Alexy II Called on Russian Teachers to Combine Education with Upbringing. Russian Information Agency. http://ria.ru/society/20040421/574130.html

Milovidov K. (2013). The Brain is Not Designed for Computer Games. Not Boring Garden. Journal of Orthodox Life. http://www.nsad.ru/articles/mozg-ne-rasschitan-na-kompyuternye-igry

Motovilov N. (2010). Conversation with saint Seraphim of Sarov on the Purpose of the Christian Life http://lib.pravmir.ru/library/readbook/1448

Rashmee R. L. (2009). Video war games satiate my feelings of aggression. The Times of India. http://timesofindia.indiatimes.com/home/sunday-times/all-that-matters/Video-war-games-satiate-myfeelings-of-aggression/articleshow/5032672.cms

Saal al-Munadzhid M. (2014). Islam for All. http://islam.com.ua/obschestvo-i-kulytura/drugoe-chast-2/10281kompyyuternye-igry

Scislowska M., d'Emilio F. (2016). Pope Francis Challenges Young People to Reject Video Games and Engage in Activism Instead. Associated Press.

http://www.independent.co.uk/news/world/europe/pope-francis-urges-young-people-to-reject-videogames-and-engage-in-activism-instead-a7164376.html

Sukhov A.A. (2016). Ethical Issues of Computer Games. $3^{\text {rd }}$ International Scientific Conference on Social Sciences and Arts. Conference Proceedings. Book 3 Anthropology, Archaeology, History and Philosophy. Volume II. Pp. 663-671. 